\title{
DOING POLITICS, DOING GENDER, DOING POWER
}

Published in Comparative Social Research, 2003, vol 21:9-28

Anne Krogstad, University of Oslo

anne.krogstad@sosgeo.uio.no

Kirsten Gomard, University of Aarhus

kvinkg@hum.au.dk

Department of Sociology and Human Geography University of Oslo

P.O.Box 1096 Blindern

N-0317 OSLO Norway

Telephone: $\quad+4722855257$

Fax: $\quad+4722855253$

Internet: http://www.iss.uio.no 


\section{DOING POLITICS, DOING GENDER, DOING POWER}

\section{Anne Krogstad and Kirsten Gomard}

\section{INTRODUCTION}

Political communication is not first and foremost about truth; it is a struggle for power and influence between different interests. In this struggle, it is critical for politicians to persuade voters, and not just by the power of their argument, but also, and increasingly, through creating trust by means of their personality. In this study we will focus on how politicians attend to these concerns in televised election campaign debates in the Nordic countries. Ideally, political debates provide politicians with equal opportunities for airing their positions. This linguistic ideal of fairness has more elaborate equivalents in established theories of discourse, such as the theory of the ideal speech situation proposed by Habermas (1975a, b), Paul Grice's maxims for efficient and logical communication (Grice, 1975), and the face-saving traffic rules of social interaction analyzed by Goffman (1967). However, this rudimentary standard of fairness is rarely satisfied in practice (Gastil, 1992). Rather than granting all participants equality, debates often become events in which prior inequalities, such as gender, age, class and status, are re-enacted (Edelsky \& Adams, 1990). The question we are pursuing in this article is whether and how such "brought along" features are made relevant, or "brought about" in actual debate situations.

The examples are drawn from a recent book on. Nordic political campaign discourse: Instead of the Ideal Debate (Gomard \& Krogstad, 2001). In the book

Comparative Studies of Culture and Power

Comparative Sucial Research, Volume 21, 9-28

Copyright $(2003$ by Elsevier Ltd.

All rights of reproduction in any form reserved

ISSN: 0195-6310/doi:10.1016/S0195-6310(03)21001-2 
we analyze politicians' discursive styles and interactional dynamics in televised debates in Denmark, Finland, Norway, and Sweden during national elections and EU-referenda in the 1990s. The overall design of the book is comparative, political discourse being compared between and within political parties, between and within gender groups and between and within status groups in one, two, three or four Nordic countries. ${ }^{\prime}$ In this article, we expand on the questions posed in the book. We still ask how politicians employ, bend, or violate canonical debate rules in order to position themselves as trustworthy female and male politicians, but we also ask how they - at the same time - present themselves as powerful female and male politicians?

\section{WOMEN AND MEN IN POLITICS IN THE NORDIC COUNTRIES}

Analyzing political discourse, not least in the light of gender and power, is particularly interesting in the Nordic countries, inasmuch as they are sometimes considered a laboratory of equality. The number of female parlamentarians has increased rapidly. In $1965,8 \%$ of the world's parlamentarians were female. The average in the Nordic countries was $9 \%$. Thirty years later, in 1995, the world figure had only risen to $11 \%$, while the figures in the Nordic countries now ranged from $35 \%$ in Iceland to $40 \%$ in Sweden. In 2002, the Nordic figures were as follows: Denmark 38\%, Finland 37\%, Iceland 35\%, Norway $36 \%$ and Sweden $43 \%$.

Proportional representation, the current electoral system of the Nordic countries, is commonly held to be one of the most important factors behind the high representation of women (Wängnerud, 2000). The extensive quota systems are also regarded as being important. Wängnerud maintains that the issue of gender equality has been quite politicized in the Nordic countries, especially in Norway and Sweden. Politicians at various levels subscribe to the idea that womens' representation has an effect on the political agenda, quotas both for internal party bodies and for candidate lists are widespread, female politicians work deliberately to recruit other women, and female politicians have many contacts with women's organizations. "The Nordic model," according to some researchers, does not just secure equal opportunities; it also achieves equal results (Esping-Andersen, 1985; Sainsbury, 1988). Others maintain that this alleged equality may be overrated (Bergqvist et al., 1999; Eduards, 1991). On the background of such disputes for the macro level, the present article asks whether "equal results" can be found on the micro level of political campaign discourse of female and male politicians and how power plays a part in this. 


\section{DOING POLITICS, DOING GENDER, DOING POWER}

We regard campaign discourse not as a mere symptom reflecting particular features of the speakers, but rather as each politician's active negotiation for an image as a competent and accountable female or male politician, a negotiation going on underneath and alongside the political arguments for or against a given party, person, or issue. Our key terms for this perspective are doing gender and doing politics. To this double perspective we shall add a third term, doing power.

The first term, doing gender, refutes gender as an expression of inherent qualities (whether natural or acquired) on the part of individuals, but rather portrays it as something they do: "an ongoing activity embedded in everyday interaction" (West \& Zimmermann, 1987, p. 130). Gender is negotiated, i.e. created and re-created in interactions among people in accordance with, or in opposition to, social and cultural conceptions of masculinity and femininity. Social and cultural norms vary across cultures and change over time, yet they are fairly stable even in modern societies. They allow a certain flexibility, but a person still has to be "accountable" as a woman or a man within her or his own society. A behavior that is not gender-appropriate does not necessarily lead to a change in norms; its consequence, rather, is simply that the individual in question is not seen as "a real man" or "a real woman" (Søndergaard, 1996). However, if enough people adopt the behavior in question, the result may be a change in culturally approved standards. But not in a way that eliminates the cultural concept of two genders. Gender may be of little relevance in some situations. However, there is no way to avoid negotiating gender; all actions, trivial as well as non-conformist, may consciously or unconsciously be understood and assessed in terms of gender.

The social position of "politician" is also interactionally created and maintained. To stress the active behavior involved, we prefer the term doing politics. Doing politics in such a way as to be recognized as a competent and accountable politician by political colleagues, the media, and the voters requires "image-work" in the widest sense of the word (Krogstad, 1999). Establishing an image for oneself as a competent politician in a political debate involves, in addition to political argumentation, the interactional creation of visibility, authority, and control. This requires a certain robustness and dominance which still more closely accord, in Western societies, with traditional cultural standards of masculinity than with traditional cultural standards of femininity.

This leads up to the third term we will examine, a term which is closely intervowen with the two previously mentioned terms, namely doing power. According to Dennis H. Wrong (1997, p. 21) power is the capacity to produce intended effects on others. By focusing on the activity, the doing of power, we want to stress 
that our point of interest is how power is created and recreated, in short negotiated by individual actors at the micro-level of interaction. Two forms of power will be discussed in this article. For the purpose of analyzing the relationship that politicians try to establish between themselves and the electorate, we find it most useful to discuss persuasion. For the purpose of analyzing the interactional dynamics between differently positioned politicians in a debate, dominance will be discussed.

An integral part of doing politics is for a politician to get voters to accept his or her messages and appeals as basis of their own behavior. Since persuasion formally lacks the asymmetry of (most) power relations, some researchers would not regard persuasion as a form of power at all. Nevertheless we agree with Wrong's classification of persuasion as a form of power because it clearly represents a means by which an actor may achieve an intended effect on another's behavior. The different forms of persuasion that we examine involves the use of authoritative and non-authoritative persuasion, persuasion by communicating intimacy or distance, symbolic and argumentative persuasion, and, finally, the use of image and issue as means of persuasion. It is only in the latter study, the one on image and issue, that we have data on the effects of the persuasion.

Persuasion is in our material an issue between politicians and voters, and the voters are in principle unconstrained by considerations of penalties, rewards or any felt obligation to do what a politician wants.

Looking at the interactional dynamics among the politicians themselves calls for a different concept, namely dominance. Dominance is asymmetrical. By dominance politicians are able to make themselves heard and seen in a debate, often at the cost of other politicians. This form of power, then, may be compared to a zero sum game: what one debater gets, other debaters will lose. Although criticized for treating all women as one social class, and all men as another, the dominance theory is still an important approach in feminist analyzes of discursive interaction between women and men (Fishman, 1984; Trömel Plötz, 1996). It stresses not just male dominance in the oppression of women on the micro-level of conversation but also assumes that the asymmetry of power will be interactionally created and recreated through cooperation between the dominant and the dominated, the woman consciously or unconsciously employing her communicative skills to cooperate in her own subordination.

Doing gender, doing politics, and doing power may be in conflict with each other. This may point up dilemmas for both female and male politicians. For instance: the better a female politician becomes at doing politics and doing power, the more she may be seen as not being "a real woman." And if, on the other hand, she convincingly adjusts to a stereotypic femininity, she may be seen as not being "a real politician" or "a real powerholder." The art of becoming a successful 
woman in political life thus lies in a balancing act which may be seen as "the art of being just right" (Pedersen, 1997). Male politicians face other forms of challenges. The strong association between doing masculinity, doing politics and doing power might impose restrictions, at least on some male politicians. They have fewer opportunities to play with the repertoire of political discourse and to expand it.

The approach of this study lies in empirically investigating how female and male politicians attempt to create a powerful image for themselves in their campaign discourse on television. In short: how do these politicians go about creating a synthesis between doing femininity/masculinity, doing politics, and doing power? Four empirical studies from the earlier mentioned Nordic comparative book (Gomard \& Krogstad, 2001) are re-examined in order to make them speak to forms of persuasion. One study is re-examined as an example of interactional dynamics of dominance. The sample we use include televised debates from the final phase (the last 14 days) of campaigning in a variety of national elections in 1993 and 1994: parliamentary elections, a presidential election, and EU referenda. The number of debates examined in the studies varies between 2 and 26, and the number of politicians between 12 and 136 .

By focusing at the micro-level of human discourse and interaction we hope to cope elastically with the variations and complexities of persuasion and dominance. It is important to stress that beyond the general intention of all politicians to get the voters to vote for them, we have no way of knowing whether the forms of discursive power that politicians wield are intended or whether these forms are expressions that are localized below the level of reflexive consciousness.

\section{AUTHORITATIVE OR NON-AUTHORITATIVE PERSUASION}

The concept of ethos is a building-block in classical rhetoric, but little attention has been paid to the problem of identifying ethos argumentation in political debates. Monika Bauhr and Peter Esaiasson (2001) define an ethos argument as an argument wherein speakers seek to persuade their audience by pointing explicitly to their character or personality. As regards types of ethos argument, the authors distinguish between arguments of responsibility, arguments of competence, arguments of experience, arguments of (good) moral standard, and arguments of affinity with the audience (Fig. 1). When using any of the first four types of arguments, the persuader marks his or her superiority over the audience, whereas the fifth type of argument marks equality between persuader and audience. 


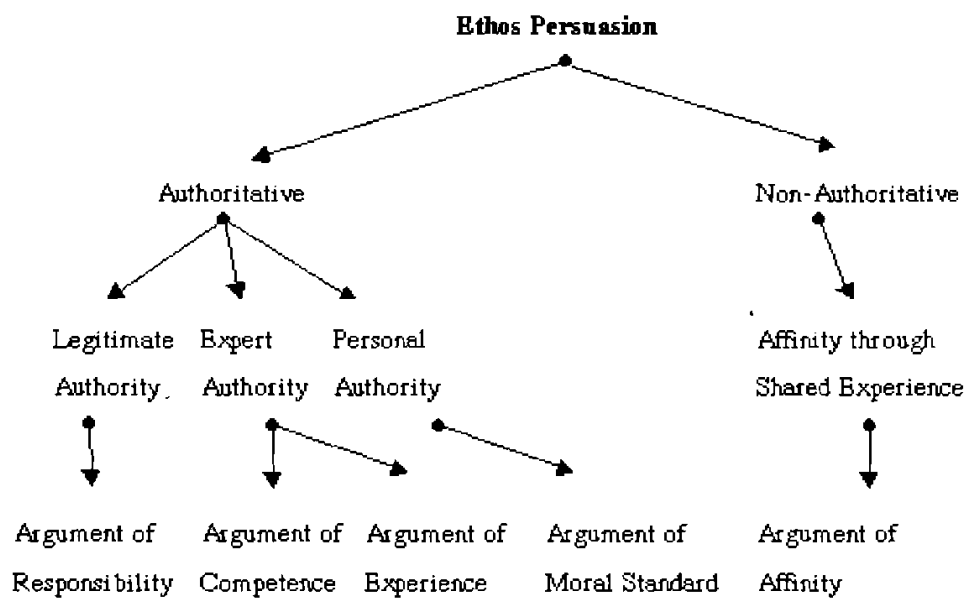

Fig. 1. A Typology of Ethos Persuasion.

Bauhr and Esaiasson use this framework to analyze persuaders' use of ethos argumentation in TV debates held during the final phase of the campaigns leading up to EU-related referenda in Denmark, Norway and Sweden. Altogether they analyze 26 debates ( 136 politicians).

The study provides some interesting findings. In the three countries the authors examine - Denmark, Norway and Sweden - superiority arguments are more common than equality arguments. In other words, the similarities are greater than the differences when it comes to the priority politicians assign to the use of authoritative versus non-authoritative ethos arguments. Cross-national differences do appear, however, in the overall frequency with which ethos arguments are used. Swedish politicians are more inclined to present ethos arguments, and especially arguments of responsibility and competence. This means that Swedish politicians underline a distance between themselves and the people - they try to persuade "from above." Danish politicians use arguments of moral standard the most, while Norwegian politicians are distinguished by a heavier use of arguments of experience. Also the Norwegian politicians use superiority arguments the least and equality arguments the most - they try to persuade by presenting themselves as women and men of the people.

The large number of ethos arguments used in Sweden may indicate that political personality plays a more important role in the Swedish campaign. Personality may also play a more prominent role in the Danish campaign than in the Norwegian one. Perhaps we could sum up by saying that the discourse of Swedish politicians is more politician-centered, while that of Norwegian 
politicians is more voter-centered. Denmark is the unmarked case. The discourse of Danish politicians displays certain elements of a politician-centered rhetoric and certain elements of a voter-centered rhetoric.

Bauhr and Esaiasson find no systematic differences between female and male politicians when it comes to the frequency with which they use ethos arguments. There are, however, some differences in the types of ethos argumentation presented by women and men. The women tend to mark affinity between themselves and their audience, while the men are inclined towards a somewhat more authoritative argumentation. There seems, in other words, to be some difference in the distance that female and male politicians create between themselves and the electorate.

Kjerstin Thelander's study of the parliamentary language of Swedish politicians indirectly supports this finding (Thelander, 1986). It concludes that the use of the pronoun we is correlated with gender: female members of the Swedish Parliament more often said we; male members more often said $I$. The same thing is demonstrated by Mats Nylund's analysis of how the use of the seemingly inconspicuous pronoun we relates to traditional issues within the area of doing politics.

\section{PERSUASION BY COMMUNICATING INTIMACY OR DISTANCE}

According to Nylund, politicians are essentially faced with two problems when trying to persuade voters during election campaigns: they must show that they are one of $u s$; and, simultaneously, they must show that they are somewhat above us that is, capable of representing us on complex political issues (Nylund, 2001). In other words, the dilemma politicians face is that they must, at one and the same time, communicate both intimacy with the audience and distance from it. Nylund focuses on electoral debates in Denmark, Finland, Norway, and Sweden, and he asks what the word we refers to.

In general, politicians talk more about we/us (and its variants ourlours) than about themselves individually ( $/ / \mathrm{me} / \mathrm{my} / \mathrm{mine}$ ). The foremost function of we in the material is to unify. By using an inclusive we, politicians project closeness to the audience and consensus with it.

Nylund also found some gender differences. Women used we a little more than twice as often as they used $I$. Men, by contrast, used we only about one-and-a-half times as often as $I$. This may be interpreted as an attempt on the part of the women (whether it is conscious or not) to include the audience, and thus to project intimacy with the voters and to downplay status and authority. Only one woman (Mona Sahlin from Sweden) - and no men - used we to indicate gender: i.e. we women. 


\section{SYMBOLIC AND ARGUMENTATIVE PERSUASION}

Nicklas Håkansson examines argumentative and symbolic style in televised party-leader debates in Denmark, Norway and Sweden (Håkansson, 2001). An argumentative style involves providing reasons for standpoints held and actions recommended. A symbolic style, by contrast, is characterized by argumentation wherein meaning is not logically negotiated. Symbolic information is condensed, emotional, and often ambiguous. Such information may be seen as a shorthand method used by speakers to create unity between themselves and the voters.

In Håkansson's evaluation of whether politicians provide reasons for their actions or standpoints, he maintains that arguments are provided in $48 \%$ of the contributions made by the contestants in the Norwegian, Danish and Swedish debates. The Norwegian politicians use the most elaborate argumentation - that is, they furnish more than one reason for their standpoint, the Danes come in a good second, and the Swedes take last place. There were also some cross-national differences in the argumentative discourse of women and men. In Norway, the women were slightly more argumentative than the men. In Denmark, it was the men who made more extensive use of this discursive style. In Sweden, finally, no differences were to be found.

Another aspect of election discourse is the use of symbolic appeals associated with the creation of identity. Hăkansson finds that symbolic appeals are more common in the Norwegian debate than in the Danish and Swedish ones. While exercising caution in the matter of generalizations, Håkansson still finds these differences to be consistent: all of the Norwegian debaters save one use identity symbols to a higher degree than their counterparts in the other two countries.

What then about gender? Håkansson found that women and men use symbolic appeals with a similar frequency, and that such appeals are associated with the creation of identity on various levels. Women and men also used arguments with a similar frequency. This finding challenges classic stereotypes to the effect that women's language is emotional and non-argumentative, and that men's is objective and rational. However, differences in styles of speech among female and male politicians often appear in the finer nuances or subtypes of a discourse category. They sneak in the back way, so to speak. The men are more inclined than the women to engage in elaborate reasoning. This difference appears systematically throughout the three countries.

In Fig. 2 Håkansson presents an overview of four styles of persuasive debate discourse. Individual politicians are categorized according to their relative use of symbols and arguments. 


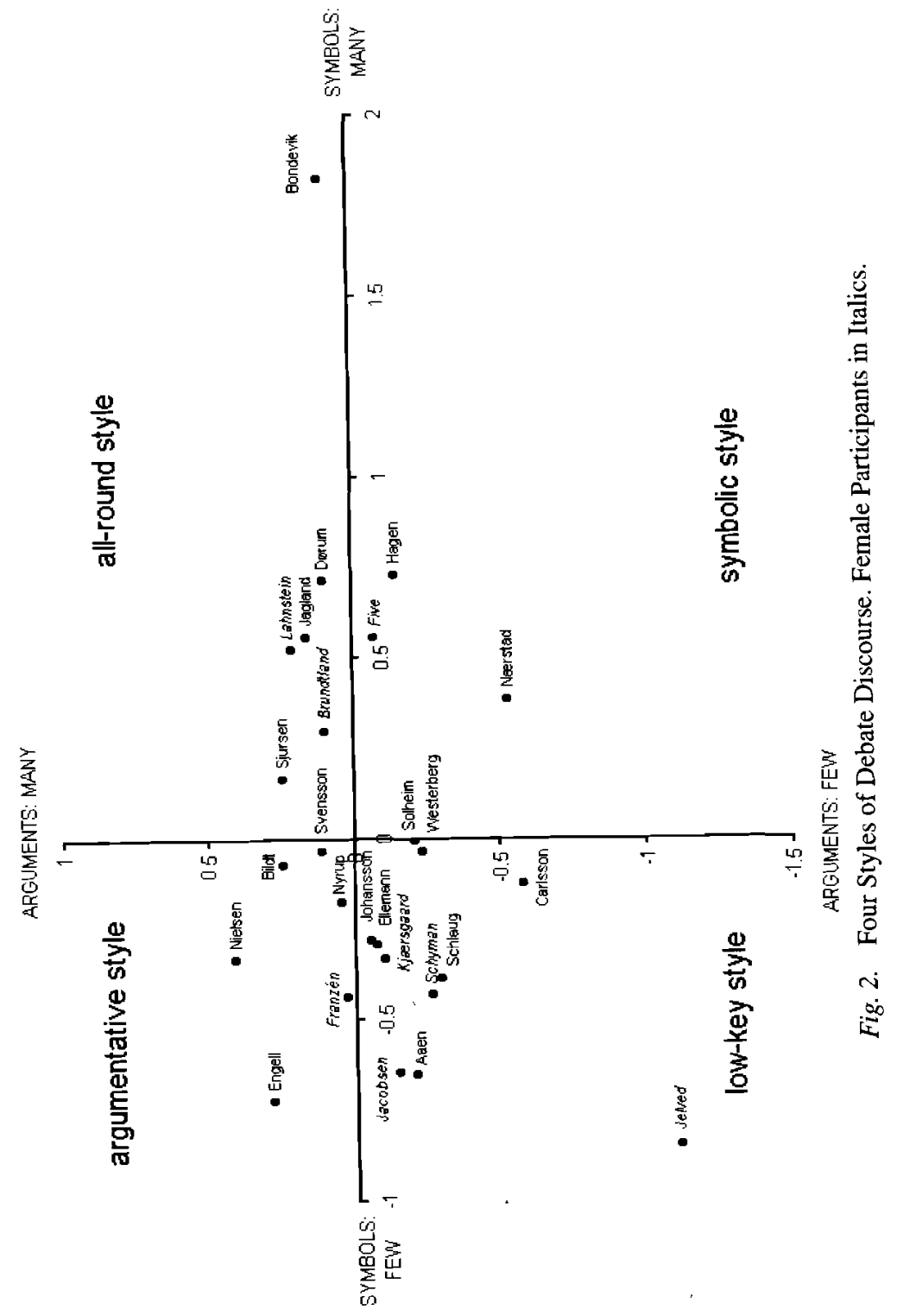


Håkansson's study reveals that the typical politician is not the one who relies exclusively on either the symbolic or the argumentative style. Rather, it is the one who combines the two. Women are well-represented both among the all-round persuaders (those with a frequent use of both symbols and arguments) and among the low-key persuaders (those who make little use of either).

The group of all-round persuaders contains some of the most experienced and established politicians in Scandinavia. Former Prime Minister of Norway, Gro Harlem Brundtland, is an example of a politician who is above the average user of symbols and is slightly more argumentative than the typical participant. Former (and present) Prime Minister Kjell Magne Bondevik (Norway) uses almost four times as many identity symbols as the average debater.

\section{IMAGE AND ISSUE IN PERSUASION}

According to Theodore White (1982), a televised debate is where the struggle over issue is joined to the struggle over image. The debaters must not only explain; they must also perform. Anne Krogstad, one of the authors of this article, evaluates the complex relationship between image and issue in televised debates (Krogstad, 2001). The material consists of the final official televised debates preceding referenda on EU membership in Sweden and Norway. The aim is not to demonstrate the intuitively correct claim that issue and image are connected. Hypotheses should be riskier that that. Rather, Krogstad tries to disentangle the "messy" relationship between image and issue. Three questions are addressed: (1) How can image and issue be defined?; (2) how can image and issue be differentiated operationally? and; (3) is it true that image is more important than issue for persuaders in televised debates? The latter claim is frequently made, but rarely proven.

H. Paul Grice's maxims for efficient and logical communication provide the point of departure. In an echo of Kantian ideas, Grice's cooperative principle stresses information, honesty, brevity, relevance, and politeness. Were politicians to hold to this list of maxims, political debate would be different indeed. We would not need to watch politicians on television resort to obscurities, long elaborations, evasive maneuvers, or personal attacks. We could all go to bed earlier, and perhaps we'd sleep better too.

But - and there is a certain irony in this - issue-oriented communication of this kind may well elicit lots of yawns and rubbing of eyes. Discussions of an "ideal" and rational sort do not always create an engaging atmosphere. In fact, they can be downright boring. Therefore, Krogstad also examines violations of the rules of efficiency laid down by Grice. Five types of violation are of particular 
interest in the study: long-windedness, credit-claiming, performance, question evasion, and negative attention towards fellow debaters. While Grice's maxims are defined as central to an issue-oriented debate style, an image-oriented debate style is defined as one marked by the mentioned violations of the cooperative principle.

Tables 1 and 2 present the number of violations of the efficiency principle in the Swedish and Norwegian debates.

Before Krogstad presents the "winners" and the "losers" of the debates, she stresses that it is impossible to separate image from issue - image always involves issue and vice versa - but for analytical purposes she has tried to keep the two concepts distinct. In order to answer the question about which factor is dominant issue or image - Krogstad relates the debaters' styles of discourse to the viewers' evaluations of the politicians as revealed in polls conducted immediately after the debates. The central finding of the study is this: in order to communicate efficiently, debaters must first attend to what Krogstad has defined as their images. The debaters with many violations of the cooperative principle - that is, the most image-oriented debaters - are the winners in the eyes of the viewers. The most issue-oriented debaters are the losers.

When gender enters the picture, this conclusion still holds, but with one qualification. Negative attention towards fellow debaters, which is a central element of any political debate, is where doing politics and doing power seems to be most in conflict with doing femininity, and more in accordance with doing masculinity. Anne Enger Lahnstein, the only woman among five men in the Norwegian debate, has many violations of the cooperative principle. Her frequent violations (especially her long-windedness and credit-claiming) are in accordance with what we might term doing politics and doing power the traditional way; however, her highly personal down-to-earth and non-aggressive rhetorical style is more in accordance with what is often associated with doing femininity. The contrast with Agneta Stark's performance in the Swedish debate is interesting. Stark has few violations of the cooperative principle, which is in accordance with doing femininity, but her rhetoric tends towards a traditional logos docere style and is more in accordance with traditional ways of doing politics. The two women, who both received favorable evaluations by the viewers, combine doing femininity and doing politics/power in different ways. Lahnstein is a "polite" rule-breaker. Stark, "the woman with the facts," is a rule-follower who adjusts to the cooperative principle, while at the same time presenting herself as an authority in a non-aggressive way. Nobody ever caught Stark napping. Whenever Ingvar Carlsson (then Prime Minister) or Carl Bildt (former Prime Minister) tried to pull a rhetorical trick on her, she would calmly explain - both to them and to the rest of the world - exactly what they were doing and why. 
Table 1. Number of Violations of the Efficiency Principle in the Swedish Debate.

\begin{tabular}{lccccccc}
\hline & Long-Windedness & Credit-Claims & Performance & $\begin{array}{c}\text { Question } \\
\text { Evasion }\end{array}$ & $\begin{array}{c}\text { Neg. Att. Towards } \\
\text { Fellow Debaters }\end{array}$ & $\begin{array}{c}\text { Total Number } \\
\text { of Violations }\end{array}$ & Violations (\%) \\
\hline Kenth Pettersson (no) & 5 & 6 & 6 & 5 & 3 & 25 & 11 \\
Eva Hellstrand (no) & 6 & 8 & 4 & 2 & 3 & 23 & 10 \\
Agneta Stark (no) & 3 & 5 & 13 & 2 & 5 & 15 & 28 \\
Carl Bildt (yes) & 7 & 12 & 20 & 0 & 14 & 69 & 24 \\
Ingvar Carlsson (yes) & 6 & 22 & 25 & 2 & 2 & 27 & 12 \\
Marit Paulsen (yes) & 7 & 4 & 12 & 2 & 42 & 226 & 100 \\
Total & 34 & 57 & 80 & 13 & & & \\
\hline
\end{tabular}

Note: Female participants in italics. 
Table 2. Number of Violations of the Efficiency Principle in the Norwegian Debate.

\begin{tabular}{lccccccc}
\hline & Long-Windedness & Credit-Claims & Performance & $\begin{array}{c}\text { Question } \\
\text { Evasion }\end{array}$ & $\begin{array}{c}\text { Neg. Att. Towards } \\
\text { Fellow Debaters }\end{array}$ & $\begin{array}{c}\text { Total Number } \\
\text { of Violations }\end{array}$ & Violations (\%) \\
\hline Anne E. Lahnstein (no) & 12 & 11 & 8 & 12 & 4 & 47 & 25 \\
Hallvard Bakke (no) & 7 & 1 & 3 & 3 & 5 & 19 & 10 \\
Stein Ørnhøi (no) & 9 & 3 & 9 & 7 & 12 & 40 & 21 \\
Thorbjørn Jagland (yes) & 4 & 2 & 14 & 3 & 7 & 30 & 16 \\
Jan Petersen (yes) & 3 & 2 & 5 & 0 & 11 & 21 & 11 \\
Thorvald Stoltenberg (yes) & 13 & 11 & 6 & 0 & 1 & 31 & 17 \\
Total & 48 & 30 & 45 & 25 & 40 & 188 & 100 \\
\hline
\end{tabular}

Note: Female participants in italics. 


\section{DOMINANCE}

Kirsten Gomard, the other author of this article, analyzes communicative styles of Danish politicians in eleven single-party debates leading up to one of the many Danish EU-referendums. The politicians - mostly in panels of three - were not debating each other as in the studies presented above, but were, on the contrary, supposed to establish a united front trying to persuade the voters in a phone-in program. In spite of this debate format, Gomard is able to show how interactional dominance is created and maintained in subtle ways among male and female politicians within the same panel.

She finds that the working conditions of the female politicians on the panels were slightly worse than those of the men. The women were treated as less important than the men, receiving fewer invitations to speak from the chairman and the viewers, and in some cases even being silenced or downright ignored by male political collegues or the chairman. Thus their conditions for doing politics in terms of visibility, authority and control turned out to be rather worse than those of the men. Some of the women, not surprisingly, became fairly passive under such circumstances while others fought quite hard to make themselves heard.

Gomard's most striking result concerning the communicative behavior of the politicians is the difference in the way female and male panel leaders handled the balance between the members of their panels. Most of the male party leaders created alliances with the other male panel member who was already in the stronger position, in short, they behaved as if the women either were not there or were political opponents. In contrast, the female leaders handled the internal floor distribution in a compensatory way - ensuring a better balance on the panel, even at their own disadvantage. The Danish female leaders created somewhat unfavorable working conditions for themselves, then, but they may have considered this a price worth paying, inasmuch as their promotion of other panel members served to project a unified and less hierarchical image of their party or organization. We might also think of their handling of the internal floor distribution as an "energizing" way of demonstrating power and leadership. This is in line with Hartsock's understanding of power as a positive force, e.g. as empowerment of subordinates, in contrast to power as domination or control (Hartsock, 1981).

In the Danish debates neither female panel leaders nor subordinate female panel members made a heavy use of competitive strategies. Only men (though not all the men) made aggressive attempts to capture the floor. Gomard maintains that a woman may be less accountable as a woman if she is too aggressive. What the dominance and competition among politicians in single-party panels - with the drawbacks caused for several of the female politicians - means for a party's capacity to persuade voters remains to be investigated. 
In her study on issue and image in the Norwegian and Swedish party leader debates, Krogstad (see above) also examined competitive strategies, features which are more prominent in these debates among political opponents than in the Danish single-party panels. She claims that most of the devices for an imageoriented discourse style seem to be open to female and male politicians alike. But what about personal attacks? None of the women in either the Norwegian or the Swedish debate were particularly attack-oriented. Is this because women are not supposed to show aggression, even though ritual aggression is a traditional feature of political debates? It is here, perhaps, that the stereotype of a politician conflicts with that of femininity and accords with that of masculinity. Aggressive women easily become "too much." On the other hand, women cannot - if they are to achieve visibility, authority and control - be too soft. In the debates the non-aggressive women whom the viewers rated favorably compensated for their lack of aggressiveness by violating many of the other cooperative maxims. This behavior is in line with the "toughness" displayed by female politicians as revealed in previous studies both in Norway (Krogstad, 1994) and in Denmark (Gomard, 1992). Likewise, male politicians rarely meet with success when adopting non-aggressive strategies. Unless they compensate for their lack of aggression in other ways, they easily fade into the background as compared with their more attack-oriented counterparts.

Krogstad also finds that a male politician's display of aggression must be understood in the light of the position he holds. If he is already popular, he may challenge others; however, he does not need to. Doing so may put him on the same (low) level as those he attacks. On the other hand, a man whose image needs bolstering ought to go negative. By attacking other debaters, he can draw attention to their weaknesses and upgrade his own position and power, by implicit contrast. This shows that gender and status are closely intertwined and work simultaneously.

\section{NEGOTIATING POLITICS, GENDER, AND POWER}

In this study of Nordic politicians' negotiation of gender, politics, and power we have employed two different points of departure: interactional dynamics and discursive styles. In our study of interactional dynamics - the working conditions each politician acquires and is given for negotiating politics, gender, and power - we move within a context where power is equivalent to dominance. In our study of discursive style - the styles and methods by which politicians negotiate politics, gender, and power - we move within a context where power is manifested both in terms of persuasion (vis-à-vis voters) and dominance (vis-à-vis fellow debaters). 
Looking at the campaign discourse in the light of doing power, understood as both dominance and persuasion, we found that the similarities between female and male politicians far outweigh the differences, which was to be expected as there are, after all, certain traditions and styles for doing politics. But, nonetheless, we must conclude that there are certain differences between female and male politicians both concerning working conditions and discursive styles.

The working conditions of female and male politicians were only analyzed by Gomard in the Danish single-party debates. She found that female politicians were treated as less important than their male counterparts, both by the chairman of the debate, the voters, and their own colleagues: they were ignored, corrected and silenced more often than the male politicians. That female politicians' working conditions are worse than men's are in accordance with previous findings for Denmark (Gomard, 1992), Finland (Esaiasson \& Moring, 1993), and Norway (Krogstad, 1994).

The bulk of results concern the discursive styles employed by women and men negotiating visibility, authority and control. Gender differences may be summarized under three headings:

(1) Male politicians take up more interactional "space" than female politicians Bauhr and Esaiasson found that male politicians got more floor time than female politicians in the Danish, the Norwegian, and the Swedish debates with the exception of Norwegian established politicians. According to Gomard male politicians also got more floor time than their female colleagues in the Danish single-party debates. Similar results have previously been found for Danish, Norwegian, and Swedish debates (Gomard, 1992; Krogstad, 1994; Thelander, 1986) and seem to be one of the most persistent findings internationally where public language is concerned (Pedersen, 1992).

Moreover, in Danish, Norwegian, and Swedish debates Håkansson found men to be more prone than women to using elaborate argumentation, i.e. more than one argument.

(2) Female politicians show more consideration for their political colleagues Gomard found female politicians to be less aggressive than male politicians in the Danish single-party debates, and Krogstad arrived at similar results in the Norwegian and Swedish debates. In the Danish single-party debates, Gomard also found that female panel leaders handled the internal floor distribution in such a way as to create a better balance among the panel members, even at their own expense - whereas most of the male panel leaders created an alliance between themselves and the other male politician on the panel who happened to be in the stronger position already. Such findings are in accordance with previous findings from Denmark where female politicians 
were also found to be more considerate than male politicians to colleagues in political debates (Gomard, 1994).

(3) Female politicians try to create closeness to the voters

Nylund found that the female politicians in the Danish, Finnish, Norwegian, and Swedish debates) used we twice as often as $I$ as compared to the men whose ratio we:I was 1.5:1. That female politicians used we more often than male politicians has previously been found for Swedish parliamentary debates by Thelander (1986). Furthermore, Bauhr and Esaiasson found that in ethos argumentation male politicians in the Danish, Norwegian and Swedish debates tended to communicate distance to the voters whereas female politicians rather tended to communicate intimacy.

It is tempting to speculate that some of these methods - taking up less discursive space, showing consideration for colleagues, and creating closeness to voters - are ways of doing femininity, i.e. negotiating cultural accountability as a woman (West \& Zimmermann, 1987) along with the negotiation of an image as a competent and powerful politician, and thus represents an attempt to overcome the dilemma of conflicting stereotypes faced by female politicians. Drude Dahlerup (1988) observes that Scandinavian female politicians seem to be caught between two conflicting expectations: they must prove they are just the same (i.e. just as able) as men, and at the same time they must prove they make a difference. The women studied in the Nordic project prove, to a great extent, that they are just as able as the men. Doing gender, politics, and power many of the women (and some of the men) do indeed expand the repertoire of political discourse. But leaving aside a few notable exceptions in the Danish single-party debates, it is harder to see that the women change the very rules of the game - i.e. that they make a difference concerning the premises upon which the discourse of politics in electoral debates is based. And we might add: why should they? Is this a woman's task only?

What, then, about the men? Is it possible to interpret a less aggressive attitude on the part of some male politicians as a modern way of doing masculinity and politics? This question must be considered in the light of voters' evaluations. Krogstad found that non-aggressive men were assessed negatively if they did not demonstrate dominance in other ways (e.g. by violating other cooperative principles during a debate). The material on this matter is scarce, but one may speculate that these negative evaluations on voters' part mean that male politicians enjoy, in comparison with their female counterparts, fewer opportunities to transgress traditional gender boundaries. The strong association between doing masculinity, doing politics, and doing power might thus be a restriction on some men. They have fewer opportunities to play with the repertoire of political discourse and to expand it, at least where national television debates are concerned. The conditions 
in this regard might be different, however, on the local political level as suggested by Gomard (1997).

Previous studies in the fields of gender, language and politics have found that female politicians have little to gain by stressing firmness, strength or toughness (Karvonen et al., 1995; Vatanen, 1988). Yet we have noticed some changes in this respect (although it bears stressing that our investigations into effects have been limited). On the discourse side, we find that, although the women are careful not to show aggression, they do reveal firmness and strength. And when they do show toughness, they combine it with culturally accepted forms of femininity. Where the reception side is concerned, meanwhile, we note that voters in both Sweden and Norway are not only able to accept two equal genders; they also welcome firm and powerful women. Powerful female politicians do not get bad reviews for doing gender "inappropriately." Rather, it seems, they get good reviews for combining politics, gender and power "appropriately." Is this another example, then, of women's constant refinement of "the art of being just right?" Or have Nordic women actually changed the ways of - and the understanding of - the triple task of doing politics, gender and power?

\section{NOTE}

1. The approach of the project is interdisciplinary. The authors are rooted in different fields of study across the humanities and the social sciences: anthropology (Anne Krogstad), gender/communication studies (Kirsten Gomard), communication studies (Mats Nylund), and political science (Peter Esaiasson, Nicklas Håkansson and Monika Bauhr). The national backgrounds of the authors cover Norway, Denmark, Finland, and Sweden.

\section{ACKNOWLEDGMENTS}

We would like to thank Anne Lise Ellingsæter and Fredrik Engelstad for valuable comments on earlier drafts of the article.

\section{REFERENCES}

Bauhr. M.. \& Esaiasson, P. (2001). Trust me! On the nature of ethos argumentation. In: K. Gomard \& A. Krogstad (Eds), Instead of the Ideal Debate. Doing Politics and Doing Gender in Nordic Political Campaign Discourse (pp. 129-154). Aarhus: Aarhus University Press.

Bergqvist, C., Borchorst, A., Christensen, A.-D., Ramstedt-Silén, V., Raaum, N. C., \& Styrkársdóttir, A. (1999). Likestilte demokratier? Kjønn og politikk i Norden. Oslo: Universitetsforlaget. 
Dahlerup, D. (1988). From a small to a large minority: Women in Scandinavian politics. Scandinavian Political Studies, I1(4), 275-298.

Edelsky, C., \& Adams, K. (1990), Creating inequality: Breaking the rules in debates. Journal of Language and Social Psychology, 9(3), 171-191.

Eduards, M. L. (1991). The Swedish gender model: Productivity, pragmatism and paternalism. West European Politics, 14(3), 166-181.

Esaiasson, P., \& Moring, T. (1993). Professionella hökar och duvor. Manliga och kvinnliga journalister frảgar ut politiker. Nordicom Information (1), 3-14.

Esping-Andersen, G. (1985). Politics against markets. Princeton: Princeton University Press.

Fishman, P. M. (1984). Macht und Ohnmacht in Pargesprächen. In: S. Trömel-Plötz (Ed.), Gewalt durch Sprache. Die Vergewaltigung von Frauen in Gesprächen (pp. 127-142). Frankfurt am Main: Fischer.

Gastil, J. (1992). Undemocratic discourse: A review of theory and research on political discourse. Discourse \& Society, 3(4), 469-500.

Goffman, E. (1967). Interaction ritual: Essays on face-to-face behavior. New York: Pantheon Books.

Gomard, K. (1992). Working conditions and communicative strategies of women candidates in TVelection campaigns. In: B.-L. Gunnarsson \& C. Liberg (Eds), Språk, Språkbrukoch kön. Rapport från ASLA:snordiska symposium Uppsala, 7-9 November 1991 (pp. 311-320). Uppsala: ASLA.

Gomard, K. (1994). Gender and political language in Denmark: Theories, methods, and problems for research. Working Papers on Language, Gender, and Sexism, 4(2), 63-84.

Gomard, K. (1997). Teorier om sprog, kommunikation og køn. In: P. Widell \& M. Kunфe (Eds), Møde om Udforskningen af Dansk Sprog til Minde om Peter Skautrup 1896-1996 (pp. 77-85). Aarhus Universitet: Nordisk Institut, 6.

Gomard, K., \& Krogstad, A. (Eds) (2001). Instead of the ideal debate. Doing politics and doing gender in Nordic political campaign discourse. Aarhus: Aarhus University Press.

Grice, H. P. (1975). Logic and conversation. In: P. Cole \& J. L. Morgan (Eds), Syntax and Semantics, 3, Speech Acts (pp. 41-58). New York: Academic Press.

Habermas, J. (1975a). Legitimation crisis. T. A. McCarthy (Trans.). Boston, MA: Beacon Press.

Habermas, J. (1975b). Communication and the evolution of society. T. A. McCarthy (Trans.). Boston, MA: Beacon Press.

Hartsock, N. (1981). Political change: Two perspectives on power. Quest staff and book committee. In: C. Bunch et al. (Eds), Building Feminist Theory (pp. 3-19). New York: Longman.

Håkansson, N. (2001). Argumentative and symbolic discourse in Nordic election debates. In: K. Gomard \& A. Krogstad (Eds), Instead of the Ideal Debate. Doing Politics and Doing Gender in Nordic Political Campaign Discourse (pp. 33-59). Aarhus: Aarhus University Press.

Karvonen, L., Djupsund, G., \& Carlsson, T. (1995). Political language. In: L. Karvonen \& P. Selle (Eds), Women in Nordic Politics: Closing the Gap (pp. 343-379). Aldershot: Dartmouth.

Krogstad, A. (1994). Kampen om ordet. Kvinner og menn i politisk valgkamp. In: G. Hagemann \& A. Krogstad (Eds), Høydeskrekk. Kvinner og Offentlighet (pp. 163-205). Oslo: Ad Notam Gyldendal.

Krogstad, A. (1999). Image i politikken. Visuelle og retoriske virkemidler. Oslo: Pax Forlag.

Krogstad, A. (2001). Image and issue in televised debates. In: K. Gomard \& A. Krogstad (Eds), Instead of the Ideal Debate. Doing Politics and Doing Gender in Nordic Political Campaign Discourse (pp. 155-184). Aarhus: Aarhus University Press.

Nylund, M. (2001). Projecting unity: Strategical uses of We in televised debates. In: K. Gomard \& A. Krogstad (Eds), Instead of the Ideal Debate. Doing Politics and Doing Gender in Nordic Political Campaign Discourse (pp. 97-128). Aarhus: Aarhus University Press. 
Pedersen, I. L. (1992). Kvindeligt og/eller offentligt sprog? In: B.-L. Gunnarsson \& C. Liberg (Eds), Språk, språkbruk och kön. Rapport från ASLA:s nordiska symposium, Uppsala, 7-9 November 1991 (pp. 253-272). Uppsala: ASLA.

Pedersen. T. B. (1997). The art of being "just right": Language and gender - still a matter of power. NORA, 5(1), 26-33.

Sainsbury, D. (1988). The Scandinavian model and women's interests: The issue of universalism and corporatism. Scandinavian Political Studies, 1, 337-346.

Søndergaard, D. M. (1996). Tegnet på kroppen. København: Museum Tusculanum.

Thelander, K. (1986). Politikerspråk i könsperspektiv. Malmö: Liber Forlag.

Trömel Plötz, S. (1996). Frauengespräche: Sprache der Verständigung. Frankfurt am Main: Fischer.

Vatanen, L. (1988). Kansanedustajaehdokkaiden paikallisraidiomainonnasta vuoden 1987 eduskuntavaaleissa. Oy Yleisradio Ab. Suunittelu-ja tutkimusosasto, tutkimusraportti 3, Helsinki.

Wängnerud, L. (2000). Representing women. In: P. Esaiasson \& K. Heidar (Eds), Beyond Westminster and congress: The Nordic experience (pp. 133-154). Ohio: Ohio State University Press.

West, C., \& Zimmermann, D. H. (1987). Doing gender. Gender \& Society (2), 125-151.

White, T. (1982). America in search of itself. New York: Harper \& Row.

Wrong, D. H. (1997). Power. Its forms, bases, and uses. New Brunswick and London: Transaction Publishers. 